\title{
Diagnostic value of liver function tests and Entamoeba histolytica antibody studies in East Africans
}

\author{
D. P. MULlAN, A. M. WARD, S. SHAH, AND A. L. JEANES \\ From the Royal Hospital, Sheffield, and the Department of Clinical Pathology, Guy's Hospital, London
}

SYNOPSIS Liver function tests and Entamoeba histolytica (E.H.) antibody titres have been studied in a variety of tropical and liver diseases. Patients with hepatic amoebiasis had a raised E.H. antibody titre and tended to have a low pseudocholinesterase activity. In two cases of amoebic liver abscess, which were treated by aspiration and emetine, there was a remarkable drop in the E.H. antibody titre. In a number of other hepatic and tropical conditions the E.H. antibody titre was not significantly raised and the liver function tests were typical of the various conditions studied.

Serum from normal Africans and from patients with liver disease was collected in order to carry out a series of liver function tests on both normal African blood donors and on patients with a variety of liver and tropical diseases. Serum was later sent to one of us, who had no prior knowledge of the patients studied. Using an indirect fluorescent antibody method (Jeanes, 1966), antibody titres against Entamoeba histolytica were determined. The results proved interesting.

\section{MATERIAL AND METHODS}

Serum was separated and stored at $-20^{\circ} \mathrm{C}$. in Nairobi, and then sent by air to England; the serum was still frozen on arrival.

Routine liver function tests were performed by the methods currently employed in the Department of Chemical Pathology, United Sheffield Hospitals. Serum pseudocholinesterase was measured by the method of Kalow and Genest (1957), and leucine aminopeptidase, (L.A.P.) by the method of Goldbarg, Pineda, and Rutenburg (1959). Electrophoresis of the serum proteins was performed on cellulose acetate using Kohn's method (1960). The individual serum fractions were estimated after elution by the method of Shepherd and Mason (1965). Amoebic antibody levels were determined by means of a method based on the indirect fluorescent antibody technique, using smears of a stock strain of Entamoeba histolytica as antigen preparations (Jeanes, 1966). Preliminary experience has shown that titres of 1 in 64 or above are highly suggestive of amoebic infection; in normal subjects residing in non-endemic areas, however, the titre seldom exceeds 1 in 8 .

Received for publication 6 October 1966.

Correspondence: Dr. D. P. Mullan, The Royal Hospital, Sheffield, 1.
RESULTS

Table I includes results from 24 male African blood donors. All the enzyme tests were normal except for some elevation of the alkaline phosphatase and L.A.P. activity in case 7 . The $\gamma$ globulin was increased in 10 cases, and case 12 had a positive thymol flocculation test. Elevation of the $\gamma$ globulin in the normal Negro may be racially determined (Edozien, 1957; Siegel, Lee, Ginsberg, Schultz, and Wong, 1965 ) and is not necessarily a reflection of chronic infection.

TABLE I

RESULTS IN 24 MALE AFRICAN BLOOD DONORS

\begin{tabular}{|c|c|c|c|}
\hline Test & Range & Mean & S.D. \\
\hline $\begin{array}{l}\text { Direct van den Bergh } \\
\text { Serum bilirubin } \\
\text { (normal } 1.0 \mathrm{mg} . / 100 \mathrm{ml} \text {.) }\end{array}$ & $\begin{array}{l}\text { All }-\mathrm{ve} \\
0 \cdot 1-0.9^{1}\end{array}$ & 0.4 & \pm \\
\hline $\begin{array}{l}\text { Thymol turbidity } \\
\text { (normal 0-4 Maclagan units) }\end{array}$ & $1-5$ & & \\
\hline Thymol flocculation & $\begin{array}{r}24-v e \\
1+v e\end{array}$ & & \\
\hline $\begin{array}{l}\text { Serum alkaline phosphatase } \\
\text { (normal 3-13 King units) }\end{array}$ & $5-20^{1}$ & 11 & $\pm \mathbf{4 \cdot 0}$ \\
\hline $\begin{array}{l}\text { Serum pseudocholinesterase } \\
\text { (normal 30-90 units } / \mathrm{ml} \text {.) }\end{array}$ & 44-82 & 60 & \pm 11 \\
\hline Dibucaine number & $74-90$ & & \\
\hline $\begin{array}{l}\text { Aspartate aminotransferase (S.G.O.T.) } \\
\text { (normal 29-116 King units) }\end{array}$ & $20-100$ & 45 & $\pm 22 \cdot 5$ \\
\hline $\begin{array}{l}\text { Alanine aminotransferase (S.G.P.T.) } \\
\text { (normal 26-93 King units) }\end{array}$ & $15-95$ & 56 & \pm 25 \\
\hline $\begin{array}{l}\text { Leucine aminopeptidase (L.A.P.) } \\
\text { (normal 84-200 units) }\end{array}$ & $117-288^{1}$ & 156 & \pm 37 \\
\hline $\begin{array}{l}\text { Serum albumin }(\mathrm{g} . / 100 \mathrm{ml} .) \\
\text { Serum globulin }(\mathrm{g} . / 100 \mathrm{ml} .)\end{array}$ & $\begin{array}{l}3 \cdot 8-4 \cdot 8 \\
1 \cdot 5-3 \cdot 9\end{array}$ & $\begin{array}{l}4 \cdot 2 \\
2 \cdot 8\end{array}$ & $\begin{array}{ll} \pm & \cdot 28 \\
\pm & \cdot 50\end{array}$ \\
\hline
\end{tabular}

${ }^{1}$ Case 7 had the highest serum bilirubin, alkaline phosphatase, and leucine aminopeptidase levels. 
Tables II and III give results from 21 patients with a variety of diseases. In four patients repeat serum samples were obtained after an interval of four weeks in case 43, after two weeks in case 44, after 10 days in case 31 , and in case 45 five specimens were taken over a four-week period.

There were five definite cases of amoebic liver abscess. One of these (case 45) was of special interest; it was at first thought that the paiient might have acute appendicitis, but a diagnosis of amoebiasis was made when actively motile forms of Entamoeba histolytica were identified in material aspirated from the caecum at laparotomy. This patient was also found to have a small abscess in the liver. The diagnosis of amoebiasis in the other four cases was based on the aspiration of 'anchovy sauce' in two cases and response to specific treatment in the remaining two.

Six patients had typical infective hepatitis. In a further patient (case 31) the presence of cysts of Entamoeba histolytica in the stools led to a suspected diagnosis of amoebiasis; after treatment with emetine, however, the liver function tests showed deterioration and became more characteristic of infective hepatitis.

One patient (case 32) had a biopsy-proven malignant hepatoma. There were four patients with cirrhosis; two were due to infestation with Schistosoma mansoni. One patient (case 34) had been living in England for a number of years and all his liver function tests were normal. This patient originally presented with severe haematemesis, portal hypertension, and hepatosplenomegaly. Liver biopsy showed only early cirrhosis, and $S$. mansoni ova were identified in the portal tracts.

Three patients had kala azar. They all had gross splenomegaly. Splenic puncture was positive in one patient. Finally, case 40, with loa loa, presented in the ophthalmic out-patient department with an adult worm which was removed from the conjunctival sac.

Table IV indicates the amoebic antibody titre in the serum of seven normal subjects and in nine patients with a variety of liver and tropical diseases Table IVa includes four of the five patients with amoebic liver disease. Insufficient serum was available for antibody studies in the remaining case of amoebiasis. All the untreated cases had titres which ranged from 1 in 128 to 1 in 512. Among the 16 patients with no clinical evidence of amoebiasis all but two had titres below 1 in 16 and the highest titre was 1 in 32 .

TABLE II

RESULTS IN SEVERAL CONDITIONS

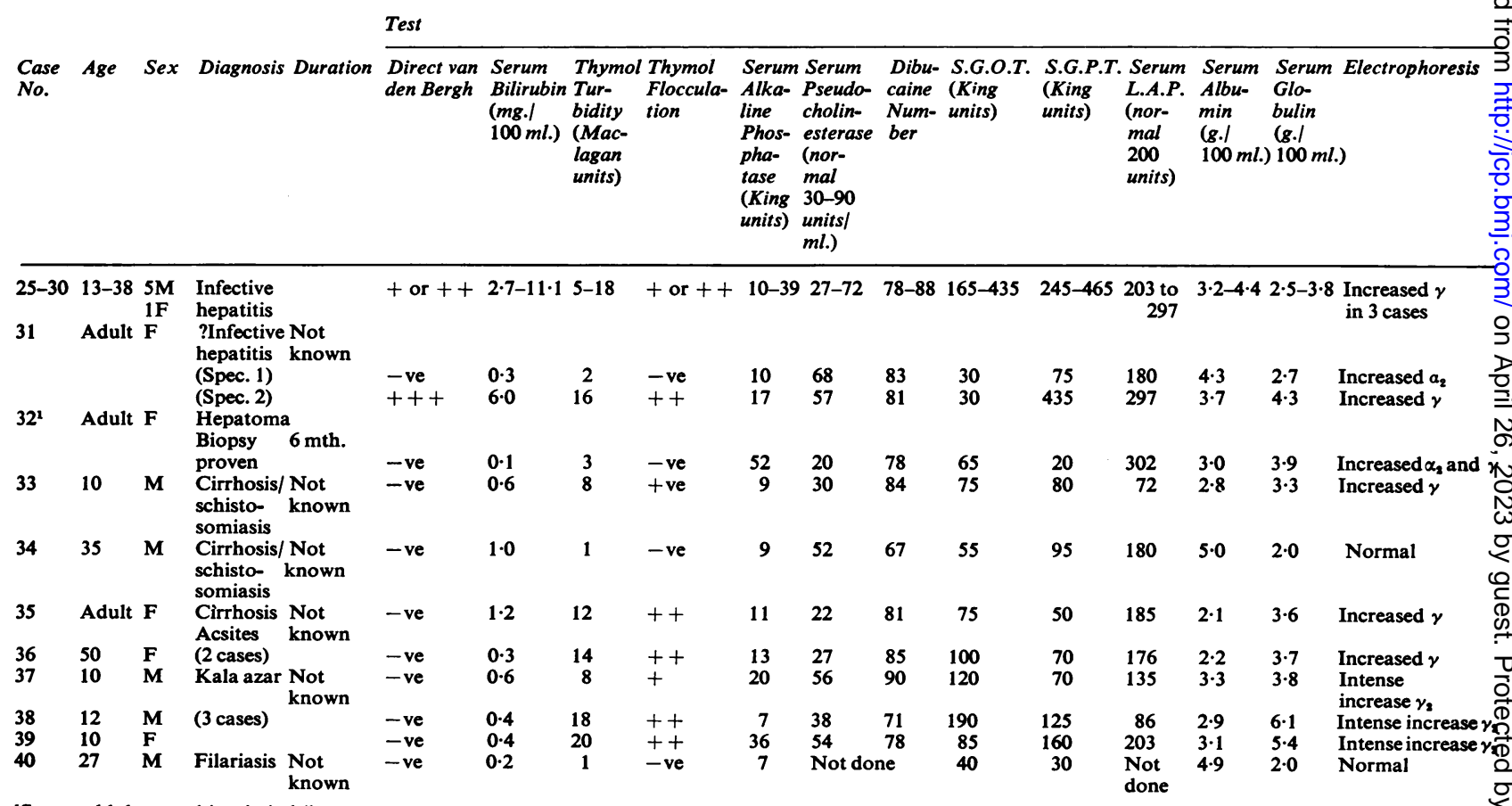


TABLE III

RESULTS IN AMOEBIASIS

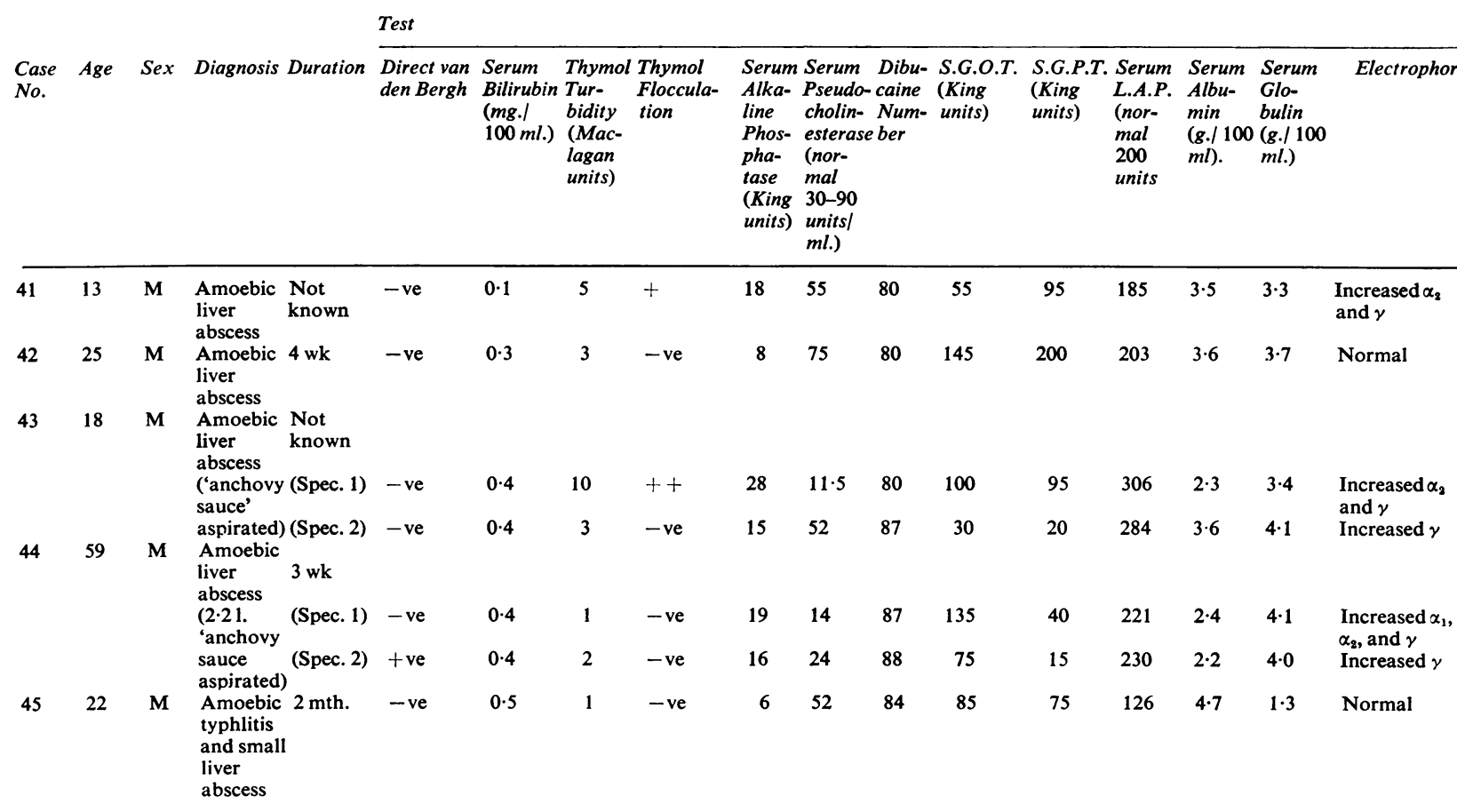

TABLE IV

INDIRECT FLUORESCENT ANTIBODY TITRES AGAINST ENTAMOEBA HISTOLYTICA

\begin{tabular}{clll} 
Case No. & Age & Sex & Antibody Titre \\
\hline Normals & & & \\
1 & 20 & M & $1: 8$ \\
5 & 19 & M & $1: 16$ \\
19 & 18 & M & $1: 8$ \\
20 & 20 & M & $1: 8$ \\
22 & 19 & M & $1: 8$ \\
23 & 19 & M & $1: 8$ \\
- & 20 & F & $1: 8$ (normal L.F.T.s) \\
& & & \\
Abnormals & & & \\
26 & 13 & M & $1: 8$ (infective hepatitis) \\
39 & 38 & M & $1: 8$ (infective hepatitis) \\
33 & 10 & M & $1: 32$ (cirrhosis/schistosomiasis) \\
34 & 35 & M & $1: 8$ (cirrhosis/schistosomiasis) \\
36 & 50 & F & $1: 8$ (cirrhosis) \\
37 & 10 & M & $1: 8$ (kala azar) \\
38 & 12 & M & $1: 8$ (kala azar) \\
40 & 27 & M & $1: 8$ (filariasis (loa loa)) \\
31 & Adult & F & $1: 8$ (? infective hepatitis)
\end{tabular}

TABLE IVa

INDIRECT FLUORESCENT ANTIBODY TITRES AGAINST ENTAMOEBA HISTOLYTICA IN CASES OF AMOEBIASIS

\begin{tabular}{|c|c|c|c|c|c|}
\hline $\begin{array}{l}\text { Case } \\
\text { No. }\end{array}$ & $\begin{array}{l}\text { Age } \\
\text { (yr.) }\end{array}$ & Sex & Diagnosis & $\begin{array}{l}\text { Antibody } \\
\text { Titre }\end{array}$ & $\begin{array}{l}\text { Pseudocholin- } \\
\text { esterase } \\
\text { (units } / \mathrm{ml} \text {.) }\end{array}$ \\
\hline 41 & 13 & $\mathbf{M}$ & $\begin{array}{l}\text { Amoebic liver } \\
\text { abscess }\end{array}$ & $1: 512$ & 55 \\
\hline \multirow[t]{2}{*}{43} & 18 & $\mathbf{M}$ & $\begin{array}{l}\text { Amoebic liver } \\
\text { abscess }\end{array}$ & & \\
\hline & & & $\begin{array}{l}\text { Before treatment } \\
\text { After treatment }\end{array}$ & $\begin{array}{l}1: 512 \\
1: 16\end{array}$ & $\begin{array}{l}11 \cdot 5 \\
52\end{array}$ \\
\hline \multirow[t]{2}{*}{44} & 59 & $\mathbf{M}$ & $\begin{array}{l}\text { Amoebic liver } \\
\text { abscess }\end{array}$ & & \\
\hline & & & $\begin{array}{l}\text { Before treatment } \\
\text { After treatment }\end{array}$ & $\begin{array}{l}1: 256 \\
1: 8\end{array}$ & $\begin{array}{l}14 \\
24\end{array}$ \\
\hline \multirow[t]{6}{*}{45} & 22 & $\mathbf{M}$ & $\begin{array}{l}\text { Amoebic typhlitis } \\
\text { and small liver } \\
\text { abscess ( } 30 \mathrm{ml} .) \\
\text { Diarrhoea for two } \\
\text { months } \\
\text { Tender over liver } \\
\text { and in R.I.F. }\end{array}$ & & \\
\hline & & & 15.10 .65 & $1: 128$ & 52 \\
\hline & & & $\begin{array}{l}\text { 16.10.65 } \\
\text { 18.10.65 Laparotomy }\end{array}$ & $\begin{array}{c}1: 128 \\
y\end{array}$ & 61 \\
\hline & & & 20.10 .65 & $1: 64$ & 51 \\
\hline & & & 30.10 .65 & $1: 64$ & 81 \\
\hline & & & 12.11 .65 & $1: 128$ & 88 \\
\hline
\end{tabular}




\section{DISCUSSION}

Recently there has been considerable interest in amoebiasis in Britain (Wright, 1966; British Medical Journal, 1966), and our research into the subject was stimulated by the death, in the Royal Hospital, Sheffield, of a man of 73 with an amoebic abscess of the left lobe of the liver which had perforated into the left lung (Mullan and Williams, 1965). In addition there have been a number of papers on the serological diagnosis of amoebiasis, using complement-fixation (Izar, 1914; Craig, 1939; Kenney, 1952; Kasliwal, Kenney, Gupta, Sethi, Tatz, and Illes, 1966), indirect haemagglutination (Kessel, Lewis, Pasquel, and Turner, 1965), gel-diffusion precipitin (Maddison, 1965; Powell, Maddison, Wilmot, and Elsdon-Dew, 1965), and immunofluorescence techniques (Jeanes, 1964, 1966).

To link the clinical findings, the results of the liver function tests, and the E.H. antibody titres appeared to be important, not only in amoebic liver disease, but also in other conditions.

LIVER ENZYMES AND SERUM PROTEIN The diagnostic value of liver function tests in amoebic disease has been investigated by a number of authors (Brem, 1955; Powell, 1959), and more recently Viranuvatti and his co-workers (Viranuvatti, Harinsuta, Plengvanit, Choungchareon, and Viranuvatti, 1963) studied 274 cases of hepatic amoebiasis. In our five cases of amoebic liver disease jaundice was absent. There was some increase in the alkaline phosphatase level in three patients and the serum L.A.P. was elevated in three cases. One patient had some increase in both S.G.O.T. and S.G.P.T. The pseudocholinesterase activity was markedly reduced in two patients who both had very low serum albumin levels, but the level of this enzyme tended to rise to normal after specific treatment. In this connexion it has already been shown that depression of the pseudocholinesterase level is a useful indicator of hepatic involvement in amoebiasis (Magill and Killough, 1958), and scoline apnoea has also been described (Mullan and Williams, 1965).

To a varying degree, we have noted some increase in all the globulin fractions, and this is in agreement with other workers (Santhanagopalan, Singh, Verma, Chattarjee, and Pal, 1964; Viranuvatti, 1965). In one patient (case 44) there was a marked elevation of the $\alpha_{1}$ globulin, more distinctly seen on the cellulose acetate, as compared with the paper electrophoretic strip. On the other hand, all our patients with infective hepatitis were jaundiced; high transaminase and low pseudocholinesterase activity with abnormal thymol turbidities were typical. In these cases the serum albumin was normal but the $\alpha_{1}, \alpha_{2}$, and occasionally the $\beta$ globulin were depressed (Sunderman and Sunderman, 1957).

Case 32, with a malignant hepatoma, had interesting enzyme changes: the alkaline phosphatase and the L.A.P. levels were both raised, the transaminases and the aldolase were normal, and the pseudocholinesterase activity was reduced to 20 units $/ \mathrm{ml}$. The serum alkaline phosphatase level is usually higher in patients with malignant hepatoma (Powell, 1959) than in those with amoebic liver abscess.

Our patients with cirrhosis showed the usual marked reduction of the serum albumin and elevation of the $\gamma$ globulin. The well-compensated cirrhotic patient (case 35) showed little change in the serum protein pattern except for slight elevation of the $\gamma$ globulin. Apart from the low pseudocholinesterase levels, the enzyme tests were normal.

The three cases of kala azar showed an intense increase in the level of $\gamma_{2}$ globulin, and the Sia test was positive in all three cases. The serum albumin values were all slightly reduced, and the enzyme tests in these three patients were unremarkable.

AMOEBIC ANTIBODY STUDIES Goldman (1953, 1954, and 1959) showed that it was possible to distinguish between various species of amoeba by means of immunofluorescence techniques. A natural development of this observation is the use of a known culture of Entamoeba histolytica to detect the presence of antibodies in the serum of patients with amoebiasis.

The results obtained in this small series serve to illustrate the potential value of the indirect fluorescent antibody technique in the serological diagnosis of amoebic infections, since all the tests were performed without prior knowledge of the clinical data.

In all cases of hepatic amoebiasis, sera obtained before treatment were found to have antibody titres which ranged from 1 in 128 to 1 in 512. Of the patients without clinical evidence of amoebic infection, the majority showed no significant rise in titre, but one patient with schistosomiasis (case 33) had a titre of 1 in 32 . The finding of moderate elevations of the antibody titre in a small proportion of patients who have no clinical evidence of amoebiasis but who reside in endemic areas is in keeping with the observations of Powell et al. (1965). Using the gel-diffusion precipitin test, these authors found that $12 \%$ of 373 African patients with non-amoebic disease in the Durban area had detectable antibodies against Entamoeba histolytica and suggested that this finding was due to past or present subclinical infection by this organism. 
In one patient with symptoms of hepatitis (case 31), there was no significant rise in the antibody titre in spite of the presence of cysts of Entamoeba histolytica in the stools. It therefore seems likely that this patient was an uninfected carrier of the organism, and that the liver disease was due to some unrelated cause. This contention is supported by the marked elevation of the serum bilirubin level and by the deterioration shown by the other liver function tests following treatment with emetine.

It was noteworthy that a dramatic fall in the antibody level followed specific treatment in both cases 43 and 44, suggesting that the method may be of value in detecting recurrence of amoebic infection. On the other hand, no immediate fall took place following treatment in case 45 , although he recovered clinically and the pseudocholinesterase level rose from 52 units $\mathrm{per} / \mathrm{ml}$. to 88 units $\mathrm{per} / \mathrm{ml}$.

Much more study is required before the value of the indirect fluorescent antibody test in the serological diagnosis of amoebiasis can be fully assessed and compared with that of other methods. The results reported here, however, suggest that this technique is likely to be of considerable value in distinguishing amoebiasis from other conditions even in regions where the disease is endemic.

We wish to thank the consultant staff of the Kenyatta National Hospital, Nairobi, for their cooperation, in particular, Dr. A. T. T. Forrester and Dr. L. R. Whittaker; Professor C. H. Stuart Harris for permission to publish details of three cases, and Dr. Arthur Jordan for his assistance and encouragement.

\section{REFERENCES}

Brem, T. H. (1955). Amer. J. med. Sci., 229, 135.

British Medical Journal (1966). 1, 933.

Craig, C. F. (1939). Texas St. J. Med., 35, 554.

Edozien, J. C. (1957). J. clin. Path., 10, 276.

Goldbarg, J. A., Pineda, E. P., and Rutenburg, A. M. (1959). Amer. J. clin. Path., 32, 571.

Goldman, M. (1953). Amer. J. Hyg., 58, 319.

(1954). Ibid., 59, 318.

(1959). Proc. Soc. exp. Biol. (N.Y.), 102, 189.

Izar, G. (1914). Arch. Schiffs-u. Tropenhyg., 18, 45.

Jeanes, A. L. (1964). Brit. med. J., 2, 1531.

(1966). Ibid., 1, 1464.

Kalow, W., and Genest, K. (1957). Canad. J. Biochem., 35, 339.

Kasliwal, R. M., Kenney, M., Gupta, M. L., Sethi, J. P., Tatz, J. S. and Illes, C. H. (1966). Brit. med. J., 1, 837.

Kenney, M. (1952). Amer. J. trop. Med. Hyg., 1, 717.

Kessel, J. F., Lewis, W. P., Pasquel, C. M., and Turner, J. A. (1965). Ibid., 14, 540.

Kohn, J. (1960). In Chromatographic and Electrophoretic Techniques, vol. 2 , edited by I. Smith. Heinemann, London.

Maddison, S. E. (1965). Exp. Parasit., 16, 224.

Magill, G. B., and Killough, J. H. (1958). J. Lab. clin. Med., 51, 333.

Mullan, D. P., and Williams, N. E. (1965). Brit. med. J., 1, 235.

Powell, S. J. (1959). Amer. J. trop. Med. Hyg., 8, 331.

-, Maddison, S. E., Wilmot, A. J., and Elsdon-Dew, R. (1965). Lancet, 2, 602.

Santhanagopalan, T., Singh Verma, N. P., Chatterjee, A. K., and Pal, S. K. (1964). Indian J. Path. Bact., 7, 102.

Shepherd, H. G., and Mason, C. C. (1965). Amer. J. clin. Path., 43, 464.

Siegel, M., Lee, S. L., Ginsberg, V., Schultz, F., and Wong, W. (1965). J. Lab. clin. Med., 66, 715.

Sunderman, F. W., Jr., and Sunderman, F. W. (1957). Amer. J. clin. Path., 27, 125.

Viranuvatti, V. (1965). Personal communication.

-, Harinsuta, T., Plengvanit, U., Choungchareon, P., and Viranuvatti, V. (1963). Amer. J. Gastroent., 39, 345.

Wright, R. (1966). Brit. med. J., 1, 957. 